Jagoda Večerina Tomaić

Faculty of Philosophy

University of Zagreb
UDC 811.411.16(497.6)

DOI https://doi.org/10.18485/fid.2017.7.ch28

\title{
THE EFFORTS OF LAURA PAPO BOHORETA IN PRESERVING THE JUDEO-SPANISH LANGUAGE
}

Као резултат географске изолованости, језичке баријере (окружен локалним српско-хрватским становништвом и под турском владавином) и чињенице да се јеврејска заједница школовала у одвојеним школама без приступа за женску децу, јеврејско-шпански језик вековима је остао очуван у свом изворном облику. Када је Аустроугарска „ослободила“ Босну (1878), Босна се отворила ка другим народима, основане су државне школе са једнаким приступом за девојчице и дечаке, а званични језик наставе у школама био је српско-хрватски. Ово отварање Босне и усвајање западњачких културних достигнућа, имало је погубан утицај на матерњи језик сефардских Јевреја. Свесни опасности од пада њиховог језика у заборав, Лаура Папо Бохорета (Сарајево, 1891-1942), инсистирала је на очувању јеврејско-шпанског језика, а њен главни циљ било је спасавање од пропадања, не само језика него и богатог сефардско- босанског наслеђа.

Кључне речи: Сефарди, живот и рад Лауре Папо Бохорете, јеврејско-шпански, изумирање језика.

\section{Introduction}

Before we start to discuss the topic of preserving the Judeo-Spanish language, a brief history of the Spanish-Sephardic Jews should be told, outlining the unique language that has evolved in different ways in the different environments which they have settled, moving out in different directions, to the greatest extent during the fifteenth and sixteenth century. The Judeo-Spanish language is of Spanish origin. Jews of Spanish origin adopted the Spanish language as their mother tongue. On $31^{\text {st }}$ March 1492, Ferdinand of Aragon and Isabella of Castile issued a Decree offering the Jews two choices: either to be converted to the Catholic faith, or by July 31 to depart Spanish territory. Those Jews who neither converted to Christianity nor departed from Spain were executed. Those converted to Christianity were called "conversos", and they were under permanent surveillance 
by the Inquisition, their houses were searched making sure that the Jews who stayed behind did not secretly continue with their religious practices.

Since the destruction of the Second Temple until today Jews have maintained their identity. The most important period in the history of the Jews on the Iberian Peninsula was the period of Arab domination-economic and cultural development and revival of the Jewish language and literature. The influence of Arab culture spills over into the $13^{\text {th }}$ century from Andalusia to the Christian centres, Toledo and Barcelona. In the field of philosophy, theology and science the most prominent individuals were Maimonides and M. ben Nahman. The Jews played an important role as translators from Arabic to Hebrew, Latin and Romance languages (romance, ladino). As early as the $14^{\text {th }}$ century anti-Semitism had taken hold of the country and Jews were forced to convert to Christianity and practitioners referred to as crypto-Jews appeared.

With the expulsion from Spain in 1492 and Portugal in 1497 Western Europe inflicted a final blow on the Jews: Jews were expelled from England in 1290, from France in 1394, and from numerous German cities in the mid $14^{\text {th }}$ century. By the mid $16^{\text {th }}$ century, except for some parts of Germany and Italy there were no more Jews in Europe. Sultan Bayezid II (1481 -1512) was a wise man and upon hearing of the expulsion of Jews from Spain, sent out his emissaries to proclaim throughout his kingdom that Jews were welcome in all parts of his empire. In truth, the late Ottoman Empire had no Muslim middle class. The state authority in the Ottoman Empire was powerful, its army well equipped and strong, the population was numerous but impoverished with a small number of craftsmen, learned people (doctors, teachers, lawyers, translators...). Bayezid II needed the Jews, because they were learned, hard-working and capable. In the $16^{\text {th }}$ century the Ottoman Empire was at the height of its power, trade was booming thanks to the Jews and their knowledge of languages, and by diplomacy they managed to trade with the Christian countries, especially with Venice.

In the $16^{\text {th }}$ century the first Sephardic communities were formed in the Balkans (Thessaloniki, Istanbul, Ferrara).Cut off from the West European culture and settled in the Turkish environment, decline and decadence began to affect Sephardic culture. It was reduced to meditation and discussing the Bible and Talmud. The influence of Byzantium was far below 
the level of the impact of Arab culture in medieval Spain. Since continuity between oral tradition and the written form weakened, the oral tradition in folk language became important (Judeo-Spanish), and by the end of the $19^{\text {th }}$ century it was the only available secular literature. From the prosecution and by the second half of the $19^{\text {th }}$ century Sephardic schools operated on the same principle: only male children enrolled in schools where they learned Hebrew (translations of the scriptures from the original to Ladino), religious education, and mathematics. High schools were religious and not secular. Children gained religious education but not wide erudition in the schools at that time. There were very few exceptions. Authors - rabbis and religious teachers organized prayer books; wrote commentaries, interpretations of scripture and the Old Testament. Some works were written in Hebrew, some in Ladino, almost all in the Rashi script. Written material was widely distributed. This material can be found in the folk poetry in which national heroes and historical events were described, more as mythological than as historical facts.

\section{A key factor for the beginning of the decay and extinction of Judeo-Spanish}

Before we even start to discuss the topic of preserving the Judeo - Spanish language it is important to point out the main cause of the beginning of its decay and extinction. In Bosnia for centuries Muslims, Orthodox Catholics, Catholics and Jews (overwhelmingly Sephards) shared the same territory. Each of these communities had autonomy in education, justice and religious teaching. Despite having lived in the same area for considerable time periods, these cultures and traditions did not mix and mingle. In the Sephardic communities, only male members of the community attended school and communicated with members of other religious groups, women did not attend school, they were mostly illiterate, always at home only communicating with their neighbours, and they undertook the responsibility for storing the knowledge of language traditions and folklore. In the private setting of a family at home they communicated with each other exclusively in Judeo-Spanish.

In 1878 the Austro-Hungarian Empire occupied - liberated Bosnia, and until 1918 Bosnia was under Austro - Hungarian authority. Particularly at that time Bosnia was a backward society in cultural, educational and economic 
dimensions. As for Sephardic Jews, the Austro-Hungarian protectorate forced them to integrate into society, and what was most important female children started to attend school where lectures were given in Serbo Croatian.

Sephardic female children were allowed to mingle and mix with children of other communities and their education was not in their mother tongue but in the language of the local population. As a consequence they distanced themselves from centuries of tradition, neglected the language of their predecessors and appreciated the importance of Serbo-Croat, the language of their education.

There is considerable ambivalence in the estimation as to whether this education represented an opening of Bosnia to the West:

First, improvement of women's access to education resulted in opening the door for Sephardic women into the broader society, contacting people outside their own family.

However, at the same time adverse impacts appeared, such as neglect and endangerment of their native language, ignoring traditions and values which had been preserved for more than four centuries in the Ottoman Empire, where they had lived after being expelled from Spain.

\section{Laura Papo Bohoreta}

The issue was recognised by Laura Papo Bohoreta, a writer and the only fighter for women's and human rights at that time in Bosnia, and at the same time a strong supporter of preservation of the Judeo-Spanish language and collector of folk treasures. She was a prolific writer of plays (some have only recently been discovered), articles, and a monograph on Sephardic women. She was very adamant that women should be educated, included in the workforce, be family breadwinners, and that was an important issue at her time - between the two wars and global economic crisis which hit Bosnia particularly hard.

All her plays and articles were written in Judeo -Spanish, apart from her first drama Elvira, written in French, and several articles in German. It should be noted that Bohoreta lived at the time of the intertwining of two completely different concepts of worldview: with the annexation of Bosnia and her native Sarajevo by the Austro Hungarian monarchy that territory gradually changed, and she became deeply concerned for the existence of Sephardic tradition and culture. With the extinction of their culture and 
tradition automatically their language would also become extinct. At the same time she was aware of the importance of accepting modern views for Sephardic women, education of women in the first place and of their active participation in modern trends in Europe of that time. This ambivalence she deftly combined and found solutions from which contemporary linguists, educators and all those engaged in critical analyses of contemporary culture would profit from through a better insight into her work.

\section{The Judeo-Spanish language in early $20^{\text {th }}$ century Bosnia}

Judeo-Spanish is the language of the home, used by family members. For women who did not attend school at that time it was the only language in which they were able to express themselves, and for girls and young women attending public schools became a second language. However the younger generation started to ignore it, not only because the official language at schools was Serbo - Croatian, but the young native speakers pushed the Judeo-Spanish language to second place and were ashamed to use it in public. What was the reason? Their illiterate mothers and grandmothers communicated in Judeo Spanish, and young women and girls at that time started to attend school and became educated. The situation became ridiculous: instead of nurturing that jewel, the symbol of their survival and faith they were ashamed to use it. Many writers ascribed to this view, for example Isak Samokovlija wrote only in the Serbian language and was openly opposed to efforts to preserve "the language which is even not ours". The best example of Samokovlija's attitude toward the Sephardic language is presented in his article "Jewish Life and its Meaning":

...We willingly closed ourselves in the ghetto of our pseudo mother tongue. It is not so much religion as the fault of the Spanish jargon that we are lagging behind, and find ourselves in a time where hidden forces are more destructive than creative.

\section{Activities of Laura Papo Bohoreta focused on preserving Judeo-Spanish}

Her articles were published in the Jewish magazines printed at that time in Sarajevo (Jewish Life, Jewish Voice...The Jewish People's Aware- 
ness), and written exclusively in Judeo-Spanish. She placed so much effort in all her activities on encouraging young Sephards to preserve their rare mother tongue and value the continuity of their language in the community.

She mostly wrote plays. Why plays and not books?

a. She was certain that direct communication with the audience was more appealing to audiences and a better transmitter of her message than books.

b. She was aware of women's illiteracy and her books would mean nothing to the majority of them, but as part of the audience in a theatre they would hear her message.

c. Education for young Sephardic population at schools was in Serbo-Croatian, their mother tongue regressed, became obsolete and was replaced by Serbo Croatian.

d. The themes of her plays were taken from the lives of ordinary people with specific goals to enable the audience to identify themselves with the characters and situations presented on the stage, she simplified the language to vocabulary to remind the audience of the (almost forgotten) phrases, words, expressions used in the language spoken in their families.

\section{Creative ways to save Judeo-Spanish from oblivion applied by Bohoreta}

a) Simplifying the language to vocabulary understandable to the audience: Ahora el amor es mas ermoso ke en el tiempo tuo! (love today is more beautiful than in your time) - Linda Namer.

b) Writing short and simple sentences: Veš luke son lus ombres! (Do you see what men are like) - Avia de ser (Once upon a time).

c) Introducing many proverbs with the goal of reviving and preserving the Sephardic tradition: Pagan djustus pur pekadoris (Just pay for the sinners), Boka serada moškas no entran (in a closed mouth flies cannot enter), even her two plays are reconstructions of everyday proverbs: Madrasta - el nombre le abasta (Stepmother- the name speaks for itself), Shuegra ni de baro buena (Mother in law even made of mud is not appreciated).

d) Dancing and singing on the stage play a special role in her plays: in one-act plays Avia de ser (One Upon a Time), Pasensia vale 
mučo (Patience is Worth Gold), Tjempos pasados (Past Times), three act plays Esterka, Ožos mios (My Eyes), Elvira, Linda Namer, Eskariño (Craving), Madrasta-el nombre le abasta (Stepmother - the word speaks for itself)...

\subsection{Singing and dancing on the stage}

Petar Guberina, (1913 - 2005) Croatian linguist and phonetician, in the middle of the twentieth century insisted on the verbo-tonal and structuro-global audio-visual approaches (S.G.A.V.) to foreign language teaching and became known and appreciated globally. He opened a new window and pointed out the primacy of oral discourse, rhythm as the bearer of thoughts and feelings, facial expressions, body positions and movement, intonation, rhythm, intensity and pitch, pauses and silences, speech tempo and situation as the advantages of oral discourse over written discourse (the importance of non lexicological means of language). Professor Guberina instituted at the Faculty of Philosophy in Zagreb a Department for experimental and theoretical phonetics on multi-disciplinarity, multimodality, affectivity and subjectivity in the study of spoken language.

Nowadays in the $21^{\text {st }}$ century, teachers still use the same method in teaching foreign languages, aware that in this way students broaden their vocabulary, learn new phrases and whole sentences with less effort and what is also important acquired knowledge remains stored in their memory for longer period of time. Through songs, vocabulary and phrases are easily memorized. Bohoreta was aware of it one hundred years ago.

\subsection{Plays performed on the stage serving more didactic purposes}

Precisely for this reason it is no coincidence that dancing, singing and proverbs played an important part in her one act (Avia de ser, Pasensija vale mučo, Tjempos pasados) through three act plays (Elvira, Ožos mios, Shuegra ni de baro buena, Esterka, Madrasta el nombre le abasta). I disagree with some of her biographers claiming that her main goal was to preserve the folklore and tradition. Today we can assert as fact that her main concern was to preserve Judeo-Spanish from the oblivion. She belonged to a small group of intellectuals called Sephardic Circle (Kalmi Baruh, Vita 
Kajon, Eliezer Levi, Avram Pinto...) who strongly opposed the revival of a single Hebrew language in Eretz Israel, fully aware that it would be a final blow to Ladino, her fight to preserve the language was not unexpected.

\subsection{She lived consciously, aware of the reality and translated it into appropriate action/Eskariño/}

The ambivalence in Laura Bohoreta's opus and activities presented through her fervent encouragement of women to embrace education but at the same time she in every possible way tried to preserve Judeo-Spanish from oblivion; she was a real idealist and down to earth woman, proving by her behaviour that an educated woman could be a breadwinner. Therefore, she placed great emphasis on education, an important asset for women in order to be appreciated and accepted, able to assume responsibility of supporting and participating in the maintenance of a family. In her last, only recently discovered play Eskariño, Bohoreta elaborated on the complex situation of the language in the society of her time and the departure of Jews to Israel. At the very beginning of the play a mother fluently in JudeoSpanish addresses her daughter and her daughter's responses are in Serbo Croatian. Bohoreta in her play described a typical environment at the end of the thirtieth year of the twentieth century in the Sephardic families in Bosnia: children at that time had a passive knowledge of Judeo Spanish, they comprehended it but lost their ability to speak and even more, became ashamed of their mother tongue, considered their language as belonging to "past history/something obsolete".

Stay Here - Kedadvos aki

And it is not by chance that the mother encouraged her daughter to learn by heart a poem by Aleksa Šantić: "Stay Here". I am also of the opinion that the recently discovered play by Bohoreta Eskariño, written in 1937 was never performed on stage because of her opposition to the exodus of the Jews to Israel at that time. She sent them a message "Stay Here....." 


\section{KEDADVOS AQUI!}

Quedadvos aqui! El sol de tiera ažena No kajenta komo este muestro La komida es amarga i de lagrimas es yena $\}$

Grande y keren i konosen

Onde no aj tu gente, ni ermana ke kon ti

reste.

II.

Ken va toar mežor de sus propias madres.

I vuestra madre es esta tiera amada.

Ečad en los pinjaskos y kampos una ožada

Onde vos aboltan aj tombas de vuestros

padres!

III.

Komo una hermosa rama

Ke le arankan sus fižas keda sola y dura.

Ami sin vozotros esta tiera kedava sin ižos

I la madre jora a su kriatura

IV.

Aki todos vos keren y vos konosen

Aji para todos soš deskonesidos.

Mežores son los propios pinjaskos deznudos

Ke kampos de flores onde kamino aženo

Quedatvos aki.

\section{OSTAJTE OVDJE!}

.I

Ostajte ovdje!...Sunce tuđeg neba, Neće vas grijat kô što ovo grije;

Gorki su tamo zalogaji hljeba

Gdje svoga nema i gdje brata nije.

Od svoje majke ko će naći bolju?!

A majka vaša zemlja vam je ova;

Bacite pogled po kršu i polju,

Svuda su groblja vaših pradjedova.

.III

Za ovu zemlju oni bjehu divi,

Uzori svijetli, što je branit znaše,

U ovoj zemlji ostanite i vi, I za nju dajte vrelo krvi vaše.

.VI

Kô pusta grana, kad jesenja krila

Trgnu joj lisje i pokose ledom,

Bez vas bi majka domovina bila;

A majka plače za svojijem čedom.

Ne dajte suzi da joj s oka leti, Vrat'te se njojzi u naručju sveta;

Živite zato da možete mrijeti

$\mathrm{Na}$ njenom polju gdje vas slava sreta!

.IIV

Ovdje vas svako poznaje i voli,

A tamo niko poznati vas neće;

Bolji su svoji i krševi goli

No cvijetna polja kud se tuđin kreće.

.IIV

Ovdje vam svako bratsku ruku steže -

U tuđem svijetu za vas pelen cvjeta;

Za ove krše sve vas, sve vas veže:

Ime i jezik, bratstvo, i krv sveta,

.IIIV

Ostajte ovdje!... Sunce tuđeg neba

Neće vas grijat kô što ovo grije -

Gorki su tamo zalogaji hljeba

Gdje svoga nema i gdje brata nije... 


\section{Stay Here}

Stay here!... The sun that shines in a foreign place,

Will never warm you like the sun in your own;

The bread has a bitter taste there

Where one has no one, not even a brother.

Who would find a better mother than one's own,

And your mother is this country;

Take a look upon the limestones and the field,

Everywhere are the graveyards of your great-grandfathers.

For this country they were noble giants,

Lights who knew how to defend it,

You, too, should stay in this country,

And give the fund of your blood for it.

As a deserted bough, when the autumn winds

Tear its leaves and slash it with ice;

Your motherland would be without you,

Like a mother crying for her child.

Do not let tears run down her face,

Return to it in the world's embrace;

Live in order to be able to die

On its battlefield where glory comes to greet you!

Everybody knows and loves you here,

And nobody will recognize you there;

Even the barren limestones are better here

Than the flowers in the fields of a foreign place.

Everybody shakes your fraternal hand here-

In the foreign land, wormwood blooms for you;

For us, amongst the limestones, everything connects:

Name, language, brotherhood, and holy blood. 
Stay here!... The sun that shines in a foreign place

Will never warm you like the sun in your own-

The bread has a bitter taste there

Where one has no one, not even a brother...

\section{Bohoreta's feminism: role of educated women in the preservation of language and culture}

During the Second World War Sephardic Jewish families were massacred by the Ustasha and fascists. Numerous important written documents, evidence of the Sephardic tradition and culture were destroyed, and the work of Laura Papo Bohoreta was forgotten almost eradicated. Her fight to achieve women's equality in education made of her one of the first Sephardic feminists in the true sense of the word: she resisted the stereotype of the passive "homebound" woman even when widowed 'unable to support her family. We might assume that the circumstances of Bohoreta's life made her a fervent feminist, but this is not the case. From the very beginning of her literary career she insisted on the education of women, and by 1907 she had already translated "Mme de Girardin" from French into Judeo -Spanish. The main characters in the book are two friends, young girls who philosophically reflect on their future, advocate emancipation and refuse to let others do their thinking.

Bohoreta deliberately picked up the mentioned drama for translation (with happy ending as always). Similarly in her play discovered after her death Linda Namer she pointed out injustices as obstacles in the lives of poor girls preventing them from advancing in life. The drama Linda Namer was written in 1919, before Bohoreta was widowed and had to take care of her two little children. Bohoreta was determined to change the position of young women in the society and her plays were focused on encouraging young women to enrol at school and avoid doing the hardest and lowest paying jobs, being dependent on their husbands, fathers or older brothers. Her feminism was based on a positive attitude: first and foremost education of young women, and their position and role in society. Being a good mother, wife and a housewife should not exclude the intellectual advance- 
ment of women with the goal of attaining a position in life that would not be discriminatory. Employment of women should not just be the result of an emergency, but also preparation for the future, there should be no difference between male and female employment and no wage gap on the basis of gender. Bohoreta anticipated not only as an economic imperative but also as a socially motivated element in the formation of future generations of women and of men, the inevitability of having to adjust to the "new era". Bohoreta managed not only to feed her children but also assist and be a support to her mother, brothers and sisters thanks to her education.

\section{References:}

De Girardin, Mme Emile de (2010.): La joie fait peur. Collection populaire illustrée du Théâtre Français. Paris: Librairie Gedalge\&Cie, digital edition of the book: University of Ottawa, http://www.archive.org/ details/lajoiefaitpeu00gira.

Díaz-Mas, Paloma (1993.): Los sefardies: historia, lengua y cultura, II ed., Madrid:

Riopedras Ediciones.

Papo Bohoreta, Laura (2005.): Sephardic Woman in Bosnia. Sarajevo: Connectum (Translated from the Judeo Spanish language by Muhamed Nezirović).

Papo Bohoreta, Laura (2012.): Esterka. The book was edited by Ana Cecilia Prenz Kopušar. Historical Archives Sarajevo and BIBLIOTECA ORBIS TERTIUS/6.

Papo, Eliezer (1996.): Agada - sayings about the Passage. Jerusalem: United Synagogue of America.

Papo, Eliezer (1999.): La Megila de Saray. Jerusalem: Published by author, Dr. Eliezer Papo.

Papo, Eliezer (2000.): Sephardic Stories. Belgrade: Centre for Youth Creativity.

Papo, Isak, Ovidija, Rikica, Camhy, Gina, Nikoidski, Clarissa (1994.) Cuentos sobre los Sefardies de Sarajevo. Split: Logos (Translation in Croatian by Isak Papo).

Romero, Elena (1979.): El tearo de los sefardies orientales. Madrid: 
Consejo Superior de Investigaciones Científicas.

Šantić, Aleksa (1980.): Selected Poems. Preface by Milanović, Branko; selection by: Vešović, Marko. Sarajevo: „Veselin Masleša“.

Vidaković-Petrov, Krinka (1986.): Culture of Spanish Jews on the Yugoslav Territory. Sarajevo: Svjetlost.

\section{Dramas of Laura Papo Bohoreta:}

Papo Bohoreta, Laura (1930.): Avia de ser. Manuscript - transcribed by Dr. Eliezer Papo.

Papo Bohoreta, Laura (1939.): Tiempos pasados. manuscript - transcribed by Dr. Eliezer Papo.

Papo Bohoreta, Laura (1934.): Patience is Worth Gold - one act play translated by Dr. Eliezer Papo.

Papo Bohoreta, Laura (1931.): Ožos mios. Rukopis - transcribed by Dr. Eliezer Papo.

Papo Bohoreta, Laura (1933.): Shuegra ni de baro buena. manuscripttranscribed by Dr. Eliezer Papo.

Papo Bohoreta, Laura (1935.): Hermandat (Madrasta - il nombre le abasta). Manuscript - transcribed by Dr. Eliezer Papo.

Papo Bohoreta, Laura (1930.): Esterka. Edited by Ana Cecilia Prenz Kopušar. Historical Archives Sarajevo i BIBLIOTECA ORBIS TERTIUS / 6, 2012

Papo Bohoreta, Laura (1907.): Adela i Eduardo. Comedia en dos actos. Manuscript in Judeo-Spanish - transliterated by Jagoda Večerina Tomaić.

Papo Bohoreta, Laura (1908.): Elvira. Drame en 5 actes. Manuscript in French - transliterated Jagoda Večerina Tomaić.

Papo Bohoreta, Laura (1936.): Escariño. Drama en 3 actos. Manuscript in Judeo-Spanish - transliterated by Jagoda Večerina Tomaić.

Papo Bohoreta, Laura (1930.): Roberto i Adela. Manuscript in Judeo Spanish - transliterated by Jagoda Večerina Tomaić. 


\begin{abstract}
As a result of geographic isolation, the language barrier (surrounded by local Serbo-Croatian population and under Turkish rule) and the fact that the Jewish community was educated in separate schools with no access for female children, the Judeo-Spanish language was preserved over the centuries in its original form. When Austria-Hungary "liberated" Bosnia (1878), Bosnia opened up to other nations, public schools with equal access for girls and boys were established, and the official language of teaching at schools was Serbo-Croatian. This opening of Bosnia and adoption of Western cultural achievement had a devastating effect on the native language of the Sephardic Jews. Aware of the danger that their language would fall into oblivion, Laura Papo Bohoreta (Sarajevo, 1891-1942), insisted on preserving the Judeo-Spanish language, her main aim was rescuing from decay not only the language, but also a rich Sephardic-Bosnian heritage.
\end{abstract}

Keywords: Sephards, life and work of Laura Papo Bohoreta, Judeo-Spanish, extinction of the language.

\title{
Biographical statement
}

JAGODA VEČERINA TOMAIĆ was born in Zagreb. She graduated at the Classical Gymnasium in Zagreb and earned her BA in French language and literature and Spanish language and literature at the Faculty of Philosophy. In 1996 she earned her MSc defending her master's thesis "Post-war French Chanson-child of existentialism", and in the year 2014 earned her $\mathrm{PhD}$, her doctoral dissertation "Folklore in the Service of the Theatre and the Theatre in the Service of Folklore: Sephardic oral tradition, its place and role in the theatrical opus of Laura Papo Bohoreta”. She is currently employed as a senior lecturer at the Centre for Foreign Languages and at the Department of Judaistics at the Faculty of Philosophy in Zagreb. As regards her publications, she has translated a dozen books and written numerous articles. Her area of scientific study is Sephardic literature and culture, writing professional papers and giving lectures at home and abroad.

E-mail: jagoda.vecerina@gmail.com 